\title{
Purification and Partial Characterization of DNA-dependent RNA Polymerase from Rhodomicrobium vannielii
}

\author{
By N. W. SCOTT $\dagger$ AND C. S. DOW* \\ Department of Biological Sciences, University of Warwick, Coventry CV4 7AL, UK
}

(Received 6 November 1985 ; revised 14 February 1986)

\begin{abstract}
DNA-dependent RNA polymerase has been isolated from Rhodomicrobium vannielii. Like those from other eubacteria, the enzyme contained four subunits : beta and beta prime $\left(M_{\mathrm{r}} 155000\right)$, alpha $\left(M_{\mathrm{r}} 38000\right)$, and sigma $\left(M_{\mathrm{r}} 98000\right)$. Analysis by isoelectric focussing showed that both alpha and sigma had several forms with different isoelectric pH values. The enzyme was sensitive to rifampicin ( $5 \mathrm{ng}$ rifampicin $\mathrm{ml}^{-1}$ gave $50 \%$ inhibition) and capable of specific promoter selection with DNA from $R$. vannielii, calf thymus and phage T7D111.
\end{abstract}

\section{INTRODUCTION}

Rhodomicrobium vannielii, a member of the Rhodospirillaceae, displays two polymorphic vegetative cell cycles and an exospore cycle (Whittenbury \& Dow, 1977). Changes in cell morphology and function have been related at the molecular level to quantitative and qualitative changes in protein and RNA content (Dow et al., 1983; Potts \& Dow, 1979). Although it is not known how these modifications are regulated, cell-cycle-related changes in susceptibility to rifampicin, the inhibitor of DNA-dependent RNA polymerase (Wehrli \& Staehelin, 1971), suggest that one point of control may be promoter selection and transcription initiation $(N$. W. Scott \& C. S. Dow, unpublished data; Whittenbury \& Dow, 1977).

In eubacteria, RNA polymerase holoenzyme is a magnesium-dependent enzyme composed of at least four subunits. Two high $M_{\mathrm{r}}$ subunits, beta $(\beta)$ and beta prime $\left(\beta^{\prime}\right)$, and a third subunit alpha $(\alpha)$ constitute a core enzyme which is capable of non-specific transcription; the fourth subunit, sigma $(\sigma)$, is required for specific promoter selection (Burgess, 1976). A change in the sigma subunit can alter the promoter specificity of the enzyme; indeed sigma substitution has been shown to play a central role in the control of the Bacillus subtilis cell cycle (Doi, 1982; Losick \& Pero, 1981). Our observations on rifampicin susceptibility suggest that an analogous situation may exist in $R$. vannielii. The primary aim of this study was to identify the major components of the RNA polymerase in this organism prior to a search for any components that might be involved in the selection of cell-cycle-specific genes. In this paper we report the purification, identification and preliminary characterization of the major form of RNA polymerase in $R$. vannielii.

\section{METHODS}

Organisms and culture conditions. $R$. vannielii (strain RM5, Warwick) was grown photoheterotrophically in PM medium containing $\left(\mathrm{g} \mathrm{l}^{-1}\right)$ : sodium pyruvate, 1.5 ; sodium hydrogen malate, $1.5 ; \mathrm{NH}_{4} \mathrm{Cl}, 0.5 ; \mathrm{NaCl}, 0.4$; $\mathrm{MgSO}_{4} .7 \mathrm{H}_{2} \mathrm{O}, 0.4 ; \mathrm{CaCl}_{2}, 0.05$. The $\mathrm{pH}$ was adjusted to 6.8 with $\mathrm{KOH}$ before autoclaving and $50 \mathrm{ml} 0.1 \mathrm{M}-$ sodium phosphate pH 6.8 was added aseptically after autoclaving (Whittenbury \& Dow, 1977). Cultures were incubated under $\mathrm{N}_{2}$ at $30^{\circ} \mathrm{C}$ with an incident light intensity of approximately $3 \mathrm{~W} \mathrm{~m}^{-2}$ (tungsten light source). Cells were harvested in the late exponential phase $\left(\mathrm{OD}_{540}=1.0\right)$ using a continuous rotor in a MSE H.S. 21 centrifuge $\left(4^{\circ} \mathrm{C}\right)$. Cells for enzyme extraction were washed once with TGED buffer $(0.01 \mathrm{M}-\mathrm{Tris} / \mathrm{HCl} \mathrm{pH} 7.9$;

† Present address: School of Life Sciences, Leicester Polytechnic, Scraptoft Campus, Leicester, UK.

Abbreviation: IEF, isoelectric focussing. 
$0.1 \mathrm{mM}$-EDTA; 0.1 mM-dithiothreitol; 5\%, w/v, glycerol) (Burgess \& Jendrisak, 1975), suspended in TGED supplemented with $1 \mathrm{M}-\mathrm{NaCl}$ or with $0.01 \mathrm{M}-\mathrm{MgCl}_{2}$ (Burgess buffer $\mathrm{A}$; Burgess, 1969) and then drop-frozen in liquid nitrogen. The cells were stored either at $-20^{\circ} \mathrm{C}$ or at $-70^{\circ} \mathrm{C}$ until required. Cells were suspended in TES/sucrose buffer (50 mM-Tris/HCl; $50 \mathrm{mm-EDTA;} 50 \mathrm{mM}-\mathrm{NaCl} ; \mathrm{pH} 8.0 ; 25 \%$ w/v, sucrose) for DNA extractions.

Bacteriophage T7D111 was obtained from M. Chamberlin, University of California, Berkeley, Calif., USA. Escherichia coli $\mathrm{C}$ (Warwick) was grown to an $\mathrm{OD}_{600}$ of 0.5 in nutrient broth (Oxoid) $+0.1 \%(\mathrm{w} / \mathrm{v})$ glucose and infected with T7D111 (m.o.i. of 1 bacteriophage to 10 bacteria). Incubation was continued until lysis occurred. After centrifugation $(5000 \mathrm{~g}, 10 \mathrm{~min})$ to remove cell debris, bacteriophage were concentrated by PEG 6000 precipitation. Finally, the bacteriophage were purified using a $\mathrm{CsCl}$ gradient, dialysed against $\mathrm{TE}$ buffer (10 mMTris/HCl; $1 \mathrm{~mm}$-EDTA; pH 7.5) and stored frozen at $-20^{\circ} \mathrm{C}$ (McDonell et al., 1977).

Isolation of DNA for use as templates in transcription studies. DNA from bacteriophage T7D111 was prepared as described by Hinkle \& Chamberlin (1972). For $R$. vannielii the DNA extraction method was based on that of Marmur (1961) with the following modifications. Cells in TES/sucrose $(25 \%, \mathrm{w} / \mathrm{v})$ buffer were lysed by a single passage through a French pressure cell followed by incubation with $10 \mathrm{mg}$ lysozyme $\mathrm{ml}^{-1}\left(37^{\circ} \mathrm{C}, 10 \mathrm{~min}\right)$ and subsequent addition of EDTA $(250 \mathrm{~mm})$ and SDS $(2 \%, w / v)$. The DNA was deproteinized using phenol/chloroform/isoamyl alcohol $(25: 24: 1$, by vol.). After centrifugation $(5000 \mathrm{~g}, 20 \mathrm{~min})$ the aqueous phase was removed, and to this was added 0.1 vol. $3 \mathrm{M}$-sodium acetate and 2 vols ethanol to precipitate the DNA ( $1 \mathrm{~h}$, $-20^{\circ} \mathrm{C}$ ). The DNA was spooled from the mixture and dissolved in TE buffer, deproteinized and precipitated as above. At this stage, the DNA solution was treated with ribonuclease $\mathrm{A}\left(5 \mu \mathrm{g} \mathrm{m} \mathrm{l}^{-1}, 37^{\circ} \mathrm{C}, 1 \mathrm{~h}\right)$. The DNA solution was then deproteinized and precipitated twice more. The precipitate was stored in ethanol at $-20^{\circ} \mathrm{C}$ until required. For transcription assays the DNA was dissolved in chromosomal assay buffer $(40 \mathrm{mM}-\mathrm{Tris} / \mathrm{HCl}$ $\mathrm{pH} 7.9 ; 10 \mathrm{~mm}-\mathrm{MgCl}_{2} ; 0.1 \mathrm{mM}-\mathrm{EDTA} ; 0 \cdot 1 \mathrm{~mm}$-dithiothreitol; $40 \mathrm{~mm}-\mathrm{KCl}$ ) and dialysed against a 500 -fold excess of the same buffer.

Electrophoresis and isoelectric focussing. (i) One-dimensional PAGE. The system used in this study was based on that of Laemmli (1970). Routinely 7.5 to $10 \%(\mathrm{w} / \mathrm{v})$ acrylamide exponential gradient gels were used; they contained $0.1 \%(\mathrm{w} / \mathrm{v})$ SDS. Gels for the analysis of column fractions were run for $6 \mathrm{~h}$ at $20 \mathrm{~mA}$ constant current and stained with Coomassie brilliant blue G. Other gels were routinely run for 17 to $20 \mathrm{~h}$ ( $10 \mathrm{~mA}$ constant current) and stained with silver nitrate (Wray et al., 1981).

(ii) Two-dimensional PAGE (non-denaturing gel system). Non-denaturing rod gels $(2 \times 130 \mathrm{~mm})$ were used for the first dimension and SDS/urea gels for the second dimension. The non-denaturing gels were made up as for Laemmli gels ( 4 or $5 \%$, w/v, acrylamide) but without SDS. RNA polymerase fractions ( 1 to $20 \mu \mathrm{g}$ ) were loaded onto the first dimension in TGED storage buffer, either with or without Coomassie brilliant blue $G$. Electrophoresis was done for $17 \mathrm{~h}$ at $0.5 \mathrm{~mA}$ (constant current). After electrophoresis the rods were either frozen for storage, or sealed onto the second-dimension gel with agarose after being soaked in equilibration buffer (O'Farrell, 1975). The second-dimension gels $(10 \%, \mathrm{w} / \mathrm{v}$, acrylamide) were as above except that 4 M-urea was included in the stacking and running gels. Electrophoresis was for $24 \mathrm{~h}$ at $10 \mathrm{~mA}$ (constant current) after which the gels were stained with silver nitrate (Wray et al., 1981).

The urea was included in the second-dimension gel to reduce the likelihood of obtaining subunit dimers. This was done because evidence from our laboratory (U. Swoboda, personal communication) suggested that presoaking in O'Farrell (1975) equilibration buffer containing $2.3 \%(\mathrm{w} / \mathrm{v})$ SDS and $5 \%(\mathrm{v} / \mathrm{v}) 2$-mercaptoethanol did not give complete denaturation of complex protein structures. As the protein patterns obtained with the urea gels were the same as those obtained for one-dimensional Laemmli gels, where the extract was boiled for $5 \mathrm{~min}$ in sample buffer containing SDS $(1 \%, w / v)$ and 2 -mercaptoethanol $(5 \%, v / v)$, we believe that this problem was to a large extent overcome.

(iii) Isoelectric focussing (IEF). For the first dimension, IEF was done by the method of O'Farrell (1975). The second dimension was a 10 to $30 \%$ acrylamide gradient gel containing $0 \cdot 1 \%(\mathrm{w} / \mathrm{v}) \mathrm{SDS}$. The gels were run (10 mA constant current) until the front was $1 \mathrm{~cm}$ from the bottom of the gel, fixed with $50 \%(\mathrm{v} / \mathrm{v})$ methanol, either stained with silver nitrate (Wray et al., 1981) or treated with Amplify (Amersham), dried and fluorographed at $-70^{\circ} \mathrm{C}$ for 1 month. To obtain ${ }^{35} \mathrm{~S}$-labelled total soluble protein, $R$. vannielii cultures were incubated with ${ }^{35}$ S]methionine $\left(1 \mu \mathrm{Ci} \mathrm{ml} l^{-1}, 37 \mathrm{kBq} \mathrm{ml}^{-1} ;>800 \mathrm{Ci} \mathrm{mmol}^{-1},>30 \mathrm{TBq} \mathrm{mmol}^{-1}\right)$ for $3 \mathrm{~h}$ and prepared as described by $\mathrm{O}^{\prime}$ Farrell (1975).

Transcription assays and rifampicin sensitivity. When assaying highly purified enzyme the assay conditions were based upon those of Jaehning et al. (1979) except that ribonucleoside triphosphates (ATP, CTP, GTP) were at $1 \mathrm{mM}$ and $\left[{ }^{3} \mathrm{H}\right] \mathrm{UTP}$ was $0.5 \mathrm{mM}\left(20 \mu \mathrm{Ci} \mathrm{mol}^{-1}, 0.74 \mathrm{MBq} \mathrm{mol}^{-1}\right)$. Maximum activity was obtained if the enzyme was added to the assay tube first (at $4^{\circ} \mathrm{C}$ ) and subsequently diluted with the other components (Gonzalez et al., 1977). With these conditions a unit of activity was defined as the amount of enzyme required to incorporate $1 \mathrm{nmol}$ UMP into acid-insoluble material in $10 \mathrm{~min}$.

To assay rifampicin sensitivity the inhibitor was added to the mixture as $1 \mu \mathrm{l}$ of a solution in $50 \%(\mathrm{v} / \mathrm{v})$ ethanol. The components were mixed on ice and the DNA was added last to prevent possible formation of pre-initiation 
complexes. The assay mixture was incubated at $30^{\circ} \mathrm{C}$ for $30 \mathrm{~min}$. The reaction was stopped by the addition of $5 \mathrm{ml}$ ice-cold $5 \%$ (w/v) TCA. After 15 min the precipitates were filtered onto Whatman GF/C filters, washed three times with TCA $(3 \mathrm{ml})$, twice with absolute ethanol $(3 \mathrm{ml})$ and dried. Radioactivity was measured in a Packard Tri-carb scintillation counter in Beckman MP scintillation fluid.

Promoter selection studies. For the formation of rapid initiation complexes (Wiggs et al., 1979) holoenzyme was first diluted with the assay buffer and then incubated for $10 \mathrm{~min}$ with DNA ( $R$. vannielii, calf thymus or T7D111) at 0,30 or $37^{\circ} \mathrm{C}$. RNA synthesis was initiated by the addition of the ribonucleoside triphosphates, including [ $\left.{ }^{35} \mathrm{~S}\right] \mathrm{ATP} \alpha \mathrm{S} \quad$ (adenosine $5^{\prime}-\alpha-\left[{ }^{35} \mathrm{~S}\right]$ thiotriphosphate) $\quad\left(10 \mu \mathrm{Ci} \mathrm{ml} l^{-1}, \quad 370 \mathrm{kBq} \mathrm{ml}^{-1} ; 1201 \mathrm{Ci} \mathrm{mmol}^{-1}\right.$, 44.3 TBq mmol-1) (NEN), together with rifampicin $\left(10 \mu \mathrm{g} \mathrm{ml}^{-1}\right)$, and transfer, where applicable, to the incubation temperature. The incubation was continued for $20 \mathrm{~min}$ and stopped by the addition of $5 \mathrm{ml}$ ice-cold $5 \%$ (w/v) TCA. After $15 \mathrm{~min}$ the precipitates were filtered onto Whatman GF/C filters. The filters were washed and the radioactivity counted as described for the assay of rifampicin sensitivity.

Isolation of RNA polymerase. All procedures were done at $4{ }^{\circ} \mathrm{C}$. Cells from a heterogeneous culture ( $40 \mathrm{~g}$ wet weight) suspended in TGED $+1 \mathrm{M}-\mathrm{NaCl}(150 \mathrm{ml})$ were disrupted by three passages through a French pressure cell $(173 \mathrm{MPa})$. The proteinase inhibitor phenylmethylsulphonyl fluoride (Sigma) $\left(23 \mu \mathrm{g} \mathrm{ml}^{-1}\right)$ was added to the suspension directly after breakage. Cell debris and ribosomes were removed by centrifugation $(100000 \mathrm{~g}, 1.5 \mathrm{~h})$. The enzyme was partially purified from this supernatant by a series of ammonium sulphate precipitations as used by Burgess (1969) for the extraction of the enzyme from $E$. coli. In the first instance, the suspension was adjusted to $33 \%$ saturation by the addition of solid ammonium sulphate. The resulting precipitate was removed by centrifugation $(5000 \mathrm{~g}, 30 \mathrm{~min})$; the supernatant was adjusted to $50 \%$ saturation by the further addition of solid ammonium sulphate. After centrifugation $(5000 \mathrm{~g}, 30 \mathrm{~min})$ the pellet containing RNA polymerase was resuspended in TGED $+1 \mathrm{M}-\mathrm{NaCl}$ buffer containing ammonium sulphate at $42 \%$ saturation. The enzyme remained in the insoluble fraction and was pelleted by centrifugation $(5000 \mathrm{~g}, 30 \mathrm{~min})$. The pellet was again suspended in TGED $+1 \mathrm{M}-\mathrm{NaCl}$ containing ammonium sulphate at $42 \%$ saturation. After centrifugation this final pellet was dissolved in $5 \mathrm{ml}$ TGED buffer and then loaded onto a Bio-Gel A5 column (Bio-rad) $(25 \times 2 \mathrm{~cm})$ equilibrated with TGED $+0.5 \mathrm{M}-\mathrm{NaCl}$. The column was eluted with the same buffer with a flow rate of $20 \mathrm{ml} \mathrm{h}^{-1}$. Fractions were collected and those with a significant $A_{280}$ (measured by Uvicord) were analysed for protein content by one-dimensional PAGE. Visual inspection of the Coomassie-blue-stained gels allowed the fractions containing beta subunits of RNA polymerase to be identified. These fractions were pooled (40 ml) and precipitated by the addition of ammonium sulphate (to $50 \%$ saturation). The precipitate was dissolved in TGED buffer such that the conductivity of the solution was equal to that of TGED containing $0 \cdot 15 \mathrm{M}-\mathrm{NaCl}$. This was loaded, at a flow rate of $12 \mathrm{ml} \mathrm{h}^{-1}$, onto a calf thymus DNA-cellulose column $(20 \times 1 \mathrm{~cm})$, prepared by the method of Alberts \& Herrick (1971), that had been washed with TGED $+1.5 \mathrm{M}-\mathrm{NaCl}$ and then equilibrated with TGED $+0.15 \mathrm{M}-\mathrm{NaCl}$. The column was washed with $50 \mathrm{ml}$ TGED $+0.15 \mathrm{M}-\mathrm{NaCl}$. The bound proteins were eluted with a linear salt gradient $(60 \mathrm{ml} \mathrm{TGED}+0 \cdot 15$ to $1 \cdot 5 \mathrm{M}-\mathrm{NaCl})$. Fractions $(3 \mathrm{ml})$ were collected and analysed by one-dimensional PAGE. Fractions containing the enzyme were pooled, excluding those which contained a major contaminating protein of $M_{\mathrm{r}} 110000$. Pooled fractions were diluted with TGED such that the conductivity of the solution was equal to that of TGED buffer containing $0.11 \mathrm{M}-\mathrm{NaCl}$. This sample was loaded onto a preequilibrated (TGED + 0.11 M-NaCl) DEAE-Sephadex column (Sigma) $\left(10 \times 1 \mathrm{~cm}\right.$, flow rate $\left.12 \mathrm{ml} \mathrm{h}^{-1}\right)$. The column was washed with $30 \mathrm{ml}$ TGED + 0.11 $\mathrm{M}-\mathrm{NaCl}$. The bound enzyme was eluted with a linear salt gradient $(80 \mathrm{ml}$ TGED +0.11 to $1.0 \mathrm{M}-\mathrm{NaCl})$. Fractions $(2 \mathrm{ml})$ were collected and the enzyme containing fractions were identified by PAGE. Those containing the enzyme of the highest purity were pooled, dialysed into storage buffer and stored at $-20^{\circ} \mathrm{C}$.

\section{RESULTS AND DISCUSSION}

\section{Identification of the holoenzyme}

The aim of this study was to identify the major components of DNA-dependent RNA polymerase. Purification procedures based on the methods of Burgess (1969), Sternbach et al. (1975), the mini-prep scheme of Gross et al. (1976) and the use of a sucrose density gradient (Taylor \& Dow, 1980) allowed the identification of proteins of the correct $M_{\mathrm{r}}$ to be core subunits. It was not clear, however, which other proteins in the extracts were core-associated. To establish the identity of these subunits we partially purified RNA polymerase from a heterogeneous culture of $R$. vannielii. For this experiment, cells ( $10 \mathrm{~g}$ wet weight) suspended in Burgess buffer $\mathrm{A}$ (Burgess, 1969) were lysed by passage through a French pressure cell (137 MPa). RNA polymerase was partially purified from the cell lysate using a series of ammonium sulphate precipitations, as described in Methods, directly followed by DNA-cellulose chromatography. Eluate fractions were assayed for RNA polymerase activity using the method of Burgess (1969), 


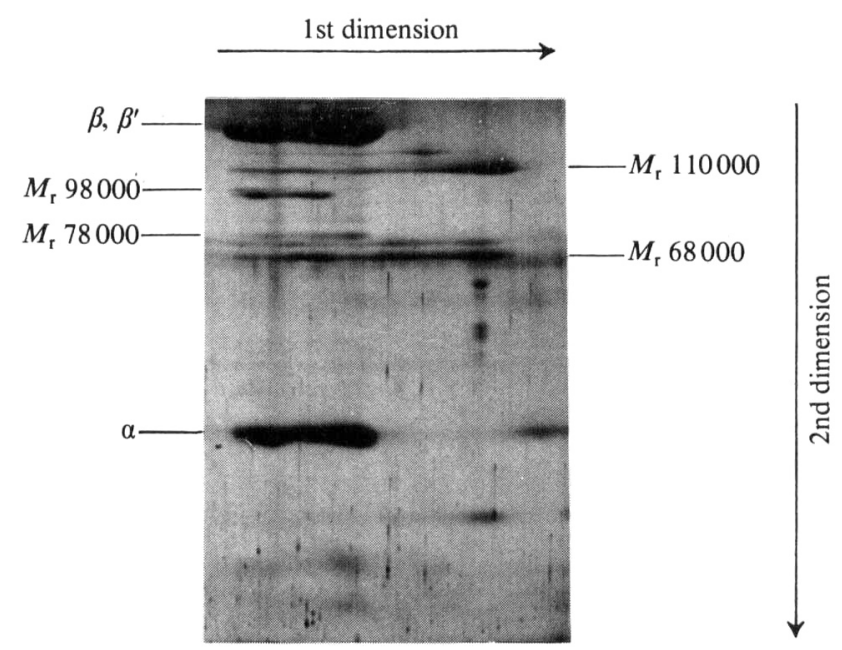

Fig. 1. Two-dimensional PAGE analysis of RNA polymerase subunit composition. Pooled extract $(20 \mu \mathrm{g})$, purified by ammonium sulphate precipitation and DNA-cellulose chromatography, was electrophoresed by the non-denaturing gel system (non-denaturing in the first dimension and denaturing in the second dimension). Two proteins $\left(M_{\mathrm{r}} 98000,78000\right)$ were associated with the core $(\beta$, $\left.\beta^{\prime}, \alpha\right)$.

and those containing enzyme were pooled, precipitated with ammonium sulphate $(50 \%$ saturation), resuspended in TGED $+0 \cdot 1 \mathrm{M}-\mathrm{NaCl}$ and dialysed against storage buffer [TGED $(50 \%, w / v$, glycerol $)+0 \cdot 1 \mathrm{M}-\mathrm{NaCl}]$. The protein content of this extract was analysed by twodimensional PAGE, a non-denaturing gel in the first dimension and denaturing gel in the second dimension. With this two-dimensional gel system it was assumed that the RNA polymerase subunits would stay associated in the first dimension, while other proteins, having different charges and $M_{\mathrm{r}}$ values, should have different mobilities in the gel. The core subunits (beta, beta prime and alpha) were identified as the most abundant proteins in the fraction by seconddimension urea/SDS PAGE (Fig. 1), and from their $M_{\mathrm{r}}$ values, which were similar to those of subunits from other organisms (see below). It was clear that the core subunits remained associated during electrophoresis in the first dimension, and that there were two proteins $\left(M_{\mathrm{r}}\right.$ 98000 and 78000 ) that had similar mobilities, suggesting that these proteins were physically associated with the core. The two other major proteins in the extract $\left(M_{\mathrm{r}} 110000\right.$ and 68000$)$ did not co-migrate with the core.

As a consequence of this gel analysis we have developed a purification system to isolate RNA polymerase containing the $M_{\mathrm{r}} 98000$ protein free of contamination with the $M_{\mathrm{r}} 110000$ protein. The isolated enzyme was found to display the transcription properties of a holoenzyme.

\section{Purification of holoenzyme}

Cell breakage and ammonium sulphate precipitations. In preliminary attempts to isolate RNA polymerase, recovery of the $M_{\mathrm{r}} 98000$ protein was poor; however, the inclusion of $1 \mathrm{M}-\mathrm{NaCl}$ in the buffer was found to increase the relative amount of this protein recovered. This was an important effect as it suggested that the $M_{\mathrm{r}} 98000$ protein was a sigma factor. It has been shown previously for other organisms that high salt concentrations reverse the DNA-binding properties of sigma subunits and the sigma-induced affinity of core for DNA (Kudo \& Doi, 1981; Kudo et al., 1981). DNAase treatment was not used, since this has been reported to introduce proteases (Burgess \& Jendrisak, 1975).

Biogel-A5 chromatography. The two proteins of $M_{\mathrm{r}} 110000$ and 68000 co-purified with the RNA polymerase, but the Biogel-A5 step reduced the amounts of these two proteins that carried through to the later stages of the purification. This step also permitted a decrease in the total 


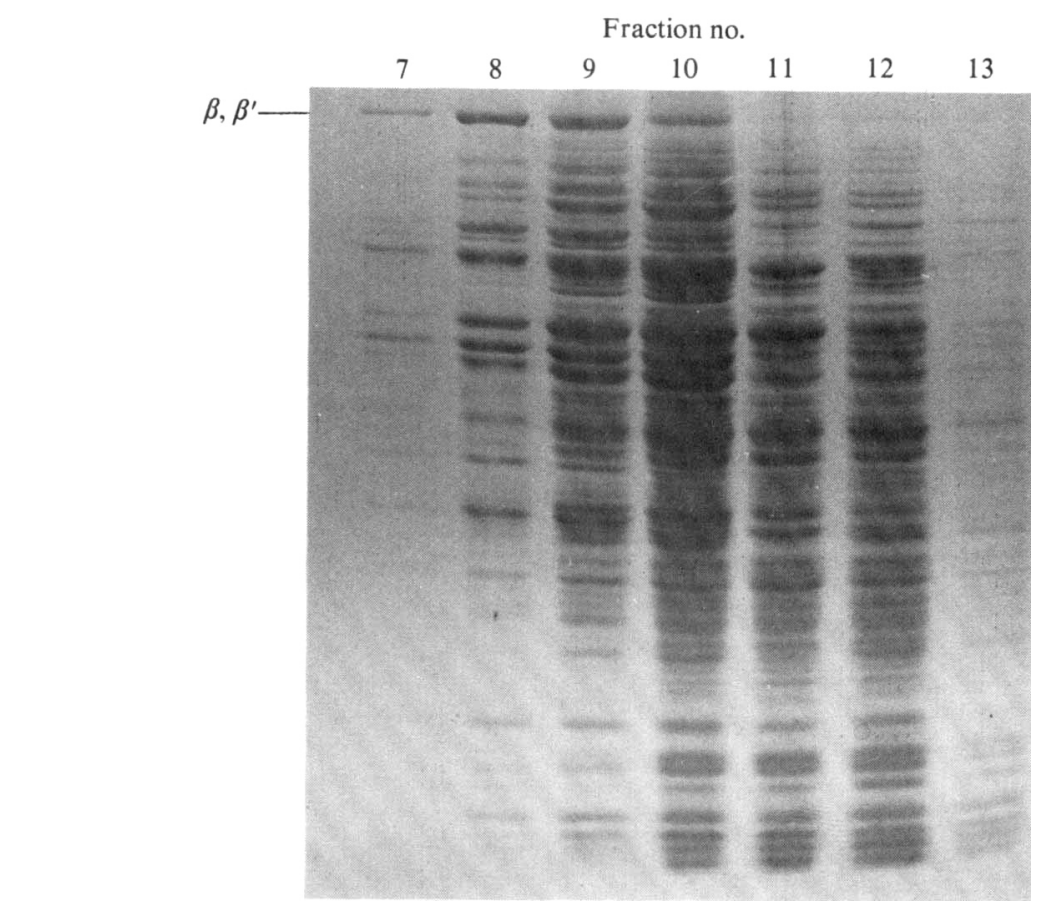

Fig. 2. Isolation of RNA polymerase by Biogel-A5 chromatography. The Coomassie-blue-stained SDS-polyacrylamide gradient gel $(7.5$ to $10 \%, \mathrm{w} / \mathrm{v}$, acrylamide) of column fractions 7 to $13(100 \mu l$ per lane) is shown.

amount of protein loaded onto the DNA-cellulose column. All of the enzyme applied to the Biogel-A5 column was recovered in four fractions, as judged by the recovery of beta and beta prime at approximately 1.8 times the void volume (Fig. 2$)$. A Uvicord scan $\left(A_{280}\right)$ indicated that these fractions contained only $50 \%$ of the protein loaded onto the column, so this step brought about a doubling in purity (data not shown). The four fractions containing the enzyme were pooled, diluted and applied to a DNA-cellulose column.

DNA-cellulose chromatography. PAGE analysis indicated that RNA polymerase eluted from the DNA-cellulose column in fractions 16 to 30 , between 0.5 and $0.75 \mathrm{M}-\mathrm{NaCl}$ (Fig. $3 a, b$ ). At this stage the enzyme extract still contained several other proteins (Fig. $3 b$ ). These were either removed or their levels were reduced in the subsequent stage. Fractions 21 to 30 were pooled and subjected to DEAE-Sephadex chromatography. The other fractions containing enzyme were discarded, since PAGE showed them to contain residual amounts of the $M_{\mathrm{r}} 110000$ and 68000 proteins (10-20\% of the enzyme).

DEAE-Sephadex chromatography. PAGE analysis (Fig. 4) showed that the enzyme eluted in four fractions from this column (between 0.2 and $0.4 \mathrm{M}-\mathrm{NaCl}$ ), with an overall recovery close to $100 \%$. From $40 \mathrm{~g}$ cells, $4.2 \mathrm{mg}$ enzyme was obtained with an initial specific activity of 830 units (mg protein $)^{-1}$. This amount of enzyme and its purity compare favourably with that purified from Caulobacter crescentus [69 $\mu \mathrm{g}$ (g cells) ${ }^{-1}$, approximately 1000 units (mg protein $)^{-1}$; Amemiya et al., 1977] and with that purified from Rhizobium leguminosarum $300[10 \mu \mathrm{g}$ (g cells) ${ }^{-1}, 310$ units (mg protein $)^{-1}$; Lotz et al., 1981]. Much greater amounts of RNA polymerase protein have been isolated from $E$. coli [e.g. $216 \mu \mathrm{g}$ (g cells) ${ }^{-1}, 1960$ units (mg protein) ${ }^{-1}$; Sternbach et al., 1975]. Differences in recovery between species may relate to growth phase of cultures, the ease of cell lysis (Lotz et al., 1981) and alterations in enzyme activity with the various templates used for assays. 

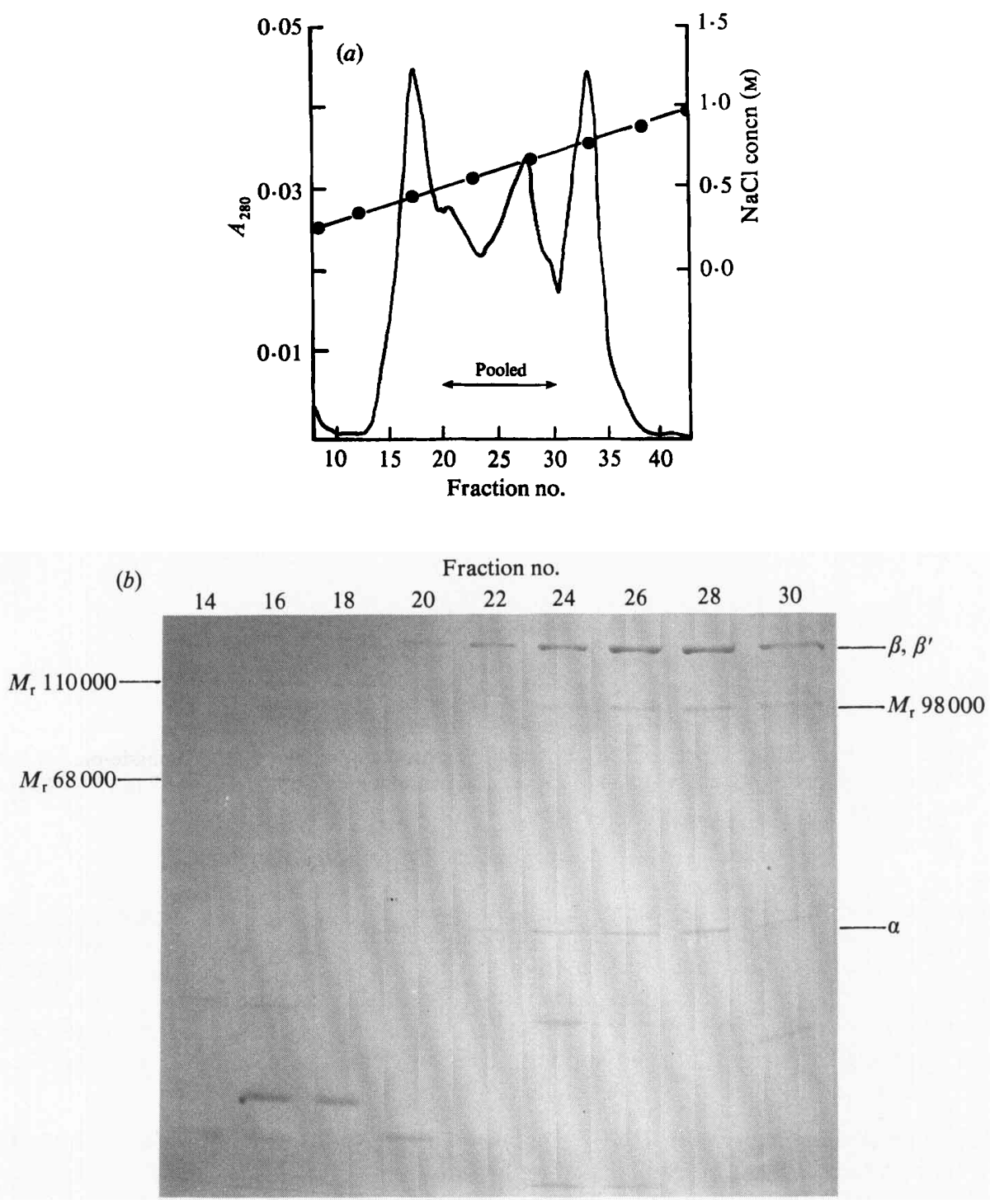

Fig. 3. Isolation of RNA polymerase by DNA-cellulose chromatography. (a) Elution profile at $A_{280}$

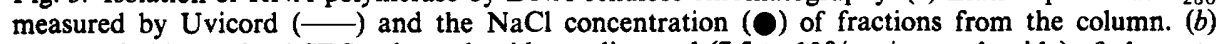
Coomassie-blue-stained SDS-polyacrylamide gradient gel ( 7.5 to $10 \%$, w/v, acrylamide) of alternate column fractions from 14 to 30 ( $50 \mu \mathrm{l}$ per lane).

\section{Properties of the holoenzyme}

Subunit composition and comparison with $E$. coli enzyme. The putative holoenzyme contained four major subunits ( $\beta, \beta^{\prime}, \alpha, M_{\mathrm{r}} 98000$ ) (Fig. 4) and subsequent use of the more sensitive silver nitrate stain (Wray et al., 1981) indicated that a minor amount of the $M_{\mathrm{r}} 78000$ protein was also present in the extract.

The approximate $M_{\mathrm{r}}$ values of the subunits were established from one-dimensional SDSPAGE by comparison with protein standards of known $M_{\mathrm{r}}$ and with $E$. coli enzyme subunits (Burgess, 1976; Ovchinnikov et al., 1981; Regensburger \& Hennecke, 1983). IEF was also used to analyse subunit composition; purified holoenzyme was electrophoresed alone (Fig. $5 a$ ) and with $\left.{ }^{35} \mathrm{~S}\right]$ methionine-labelled total soluble protein from a heterogeneous culture (Fig. $5 b, c$ ). 


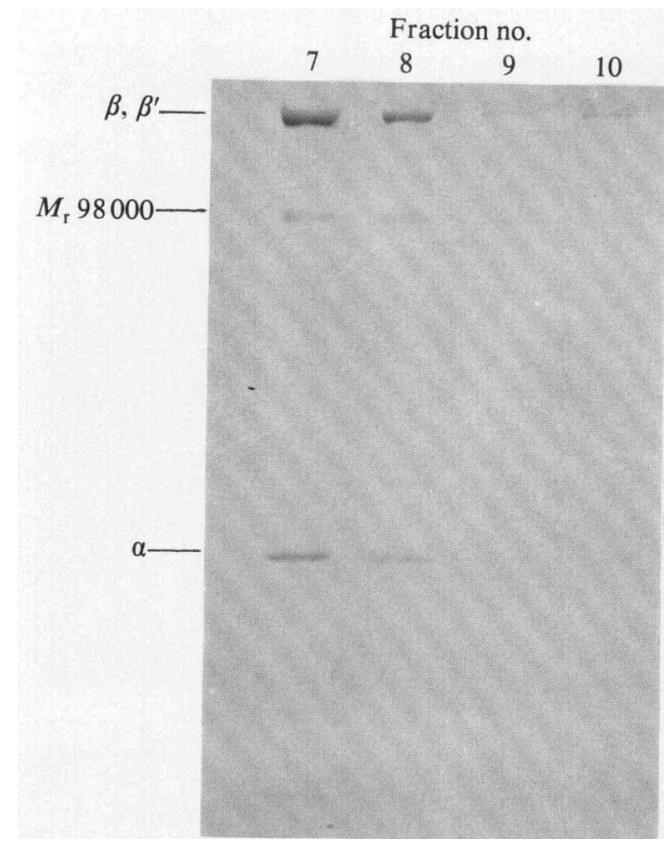

Fig. 4. Isolation of RNA polymerase by DEAE-Sephadex chromatography. Coomassie-blue-stained SDS-polyacrylamide gradient gel $(7.5$ to $10 \%$, w/v acrylamide) of column fractions 7 to $10(30 \mu l$ per lane).

From the one-dimensional gel system (data not shown) the $M_{\mathrm{r}}$ of the $R$. vannielii alpha subunit was apparently 38000 and alpha subunit isolated from $E$. coli was apparently 40000 . As the true $M_{\mathrm{r}}$ of $E$. coli alpha subunit has been calculated from sequence data to be 36512 (Ovchinnikov $e t$ al., 1977) the value for the $R$. vannielii subunit may be an overestimate. The second-dimension gel of the IEF analysis showed that the alpha subunit had several forms with different isoelectric $\mathrm{pH}$ values (Fig. 5a). However, only one form of the protein was detected on the fluorograph (Fig. 5c).

As the beta and beta-prime subunits had very similar $M_{\mathrm{r}}$ values, between 150000 and 160000 , it was difficult to separate these two subunits by PAGE (Fig. 4); however, they did have slightly different mobilities (see Fig. 3). For $E$. coli it has been found that beta prime does not enter O'Farrell IEF gels but remains at the basic end (Hayward \& Fyfe, 1978) and the largest subunit in the $R$. vannielii holoenzyme behaved similarly (Fig. 5). We therefore propose that this subunit is beta prime and the smaller subunit beta.

As the $M_{\mathrm{r}} 98000$ protein was both abundant and core-associated it was believed to be a sigma factor. This was supported by the observations, discussed below, of the transcription properties of the enzyme extract containing the $M_{\mathrm{r}} 98000$ protein.

The $M_{\mathrm{r}}$ of the 98000 protein was calculated from PAGE. Although this subunit was larger than the $E$. coli sigma subunit, it was of similar size to those from a wide range of other organisms (Burgess, 1976). This protein did not form a discrete band on one-dimensional gels (Fig. 4) but was either diffuse or in a doublet form. There have been reports of similar behaviour for the $E$. coli sigma factor (Friesen et al., 1976; Hayward \& Fyfe, 1978). However, IEF again pointed to multiple forms of the $M_{\mathrm{r}} 98000$ protein, as two spots were clearly visible on silver-stained gels (Fig. 5a). No spot was visible in the $M_{\mathrm{r}} \mathbf{9 8 0 0 0}$ position of the fluorograph after initial exposure (Fig. $5 c$ ), perhaps because the low concentration of $\mathrm{NaCl}$ in the breakage buffer was not optimal for recovery of this protein, but longer exposure allowed the detection of a protein in this position. 

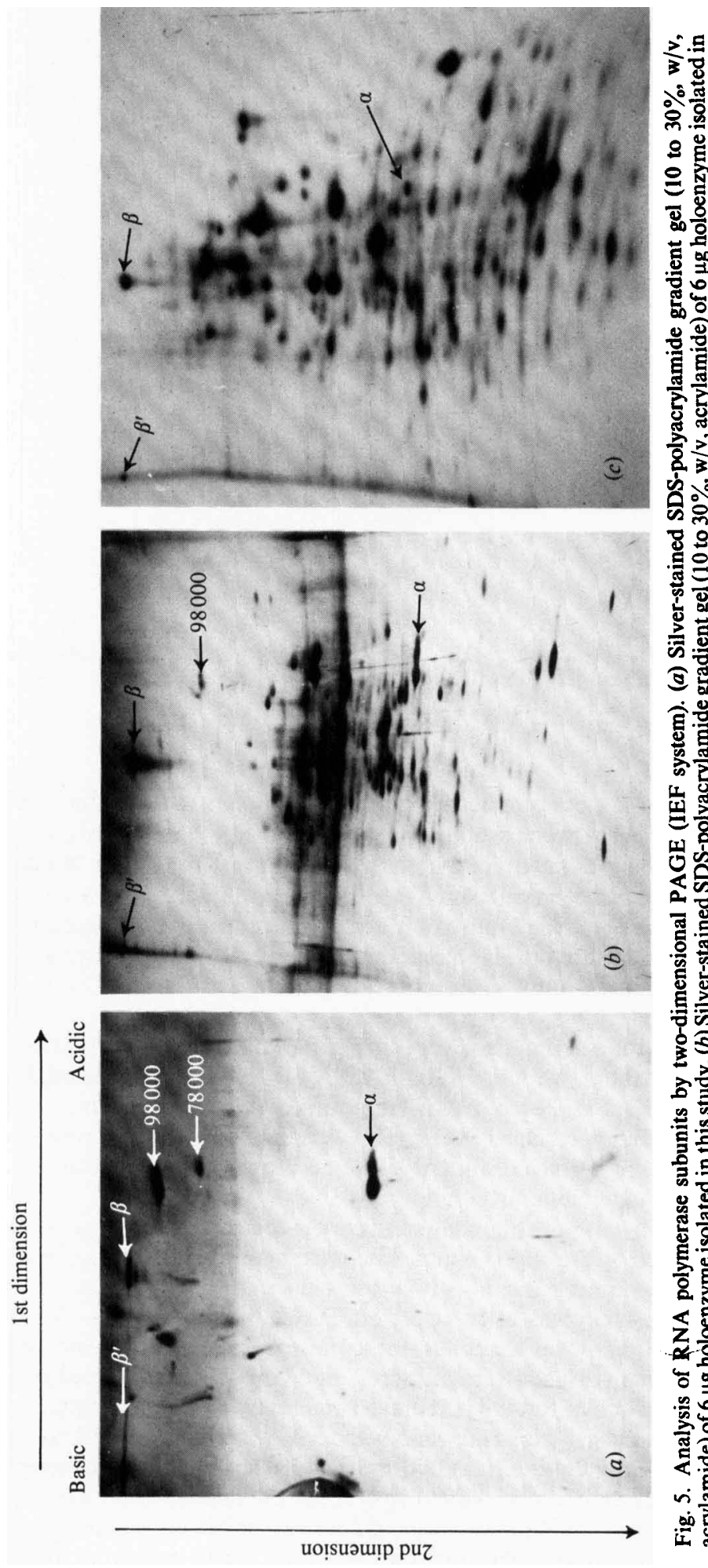

영용

正 \些 क. 을

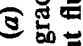
宅官

ํㅗㄹ

客震

I

를

셜

行

궁

동

फ़

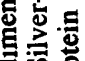

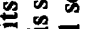

콕

므롱

造

政

․ㅗㅇ

홍를

종

乙卷용

트

을

䑻它

종응

흘 궁 
Table 1. Promoter selection by the R. vannielii holoenzyme

Each assay $(100 \mu \mathrm{l})$ contained $100 \mu \mathrm{g} \mathrm{ml}^{-1}$ enzyme and $100 \mu \mathrm{g} \mathrm{m} \mathrm{l}^{-1}$ DNA template.

Prebinding assay conditions

\begin{tabular}{|c|c|c|c|c|c|c|}
\hline \multicolumn{2}{|c|}{ Temperature $\left({ }^{\circ} \mathrm{C}\right)$} & \multicolumn{2}{|c|}{ Rifampicin } & \multicolumn{3}{|c|}{$\left.{ }^{[35} \mathrm{S}\right] \mathrm{AMP} \alpha \mathrm{S}$ incorporated (c.p.m. $\mu \mathrm{l}^{-1}$ ) } \\
\hline Before & After & & Time of & & DNA templat & \\
\hline initiation & initiation & $\mu \mathrm{g} \mathrm{ml}^{-1}$ & addition & T7D111 & Calf thymus & R. vannielit \\
\hline 30 & 30 & - & - & 209.60 & 193.00 & 32.05 \\
\hline 30 & 30 & 100 & Before template & 3.00 & 3.70 & 3.25 \\
\hline 0 & 30 & 10 & At initiation & 20.70 & 12.70 & $10 \cdot 25$ \\
\hline 30 & 30 & 10 & At initiation & 122.65 & $73 \cdot 30$ & 21.75 \\
\hline 0 & 37 & 10 & At initiation & 21.45 & 10.50 & 9.15 \\
\hline 37 & 37 & 10 & At initiation & 119.40 & $84 \cdot 10$ & 23.95 \\
\hline
\end{tabular}

One-dimensional and two-dimensional PAGE analysis indicated the presence of a small amount of the $M_{\mathrm{r}} \mathbf{7 8 0 0 0}$ protein in the holoenzyme extract. The identity of this protein was not established; however, one possibility that must be considered is that the pretreatments used for sample denaturation did not totally dissociate the alpha subunit dimers. Further analysis is required to establish whether $M_{\mathrm{r}} 78000$ is a unique protein or a form of the alpha dimer, which apparently is stable in quite powerful denaturation conditions. For one-dimensional PAGE, samples were heated at $100{ }^{\circ} \mathrm{C}$ for $5 \mathrm{~min}$ in the presence of $1 \%(\mathrm{w} / \mathrm{v})$ SDS and $5 \%(\mathrm{v} / \mathrm{v}) 2-$ mercaptoethanol, and for the IEF two-dimensional analysis, proteins were denatured by $9 \mathrm{M}$ urea for the first dimension and the rod gels were subsequently soaked in buffer containing $2.3 \%$ (w/v) SDS and 5\% (v/v) 2-mercaptoethanol. This buffer was also used to soak the nondenaturing rod gels prior to electrophoresis in the second dimension for which gels containing $0.1 \%(w / v)$ SDS and $4 \mathrm{M}$-urea were used.

Fukuda et al. (1977) showed that RNA polymerases isolated from a wide range of organisms cross-reacted with anti-E. coli holopolymerase serum. We have raised anti-serum against $\boldsymbol{R}$. vannielii holoenzyme, and with an Ouchterlony immunodiffusion system (Ouchterlony, 1958) it was found that this antibody cross-reacted with $E$. coli RNA polymerase (from Sigma), an indication that these two enzymes were also related antigenically (data not shown).

\section{Transcription properties of the holoenzyme}

Template preference. The enzyme used T7D111 and calf thymus DNA as templates with equal efficiency, but $R$. vannielii DNA was a relatively poor template; efficiency, as compared to T7D111, varied between 10 and $50 \%$ (Table 1). A similar transcription pattern has been reported for $C$. crescentus (Amemiya et al., 1977). It was not clear whether this effect was due to the $R$. vannielii DNA being damaged during purification, or whether other protein factors were required for efficient transcription. With the basic assay, transcription rates were linear for at least $30 \mathrm{~min}$ and the rate doubled if the amount of protein in the assay was doubled, indicating that the extract was free of transcription inhibitors. Assays were more efficient at $37^{\circ} \mathrm{C}$ than at $30^{\circ} \mathrm{C}$, but no difference was found for the pre-binding assays.

Formation of pre-initiation complexes. The purified enzyme displayed the properties of a holoenzyme (Wiggs et al., 1979) in that it was able to form rifampicin-resistant pre-initiation complexes with three DNA templates. The efficiency of complex formation was template specific (Table 1). In this assay, prior to transcription initiation, purified enzyme was incubated in the presence of DNA at either 0,30 or $37^{\circ} \mathrm{C}$. At the higher temperatures, enzyme was able to bind specifically to promoters to form rifampicin-resistant complexes, so that RNA synthesis was not inhibited by the addition of antibiotic at transcription initiation. At the lower temperature, however, complex formation was greatly reduced and rifampicin was able to inhibit RNA synthesis. 


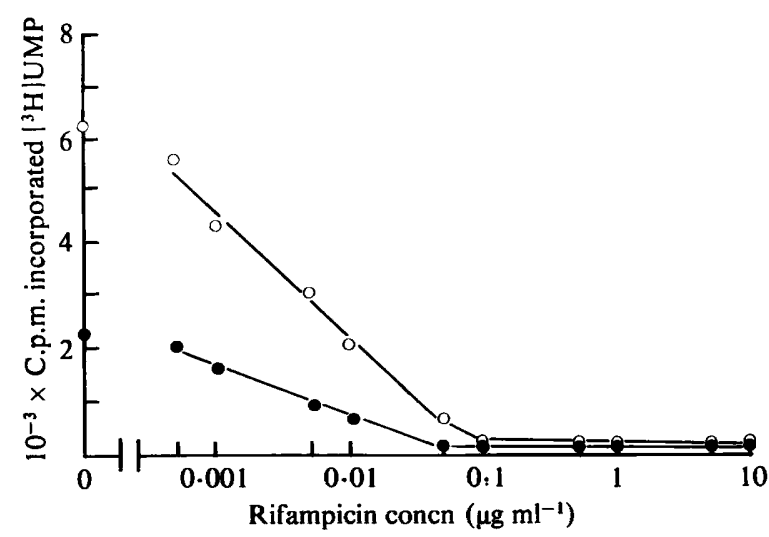

Fig. 6. Rifampicin inhibition of holoenzyme isolated in this study. Each assay contained $2.5 \mu \mathrm{g}$ protein and $10 \mu \mathrm{g}$ DNA. $O$, T7D111 DNA;,$R$. vannielii DNA.

Rifampicin sensitivity. As it has been reported that the in vivo sensitivity of $R$. vannielii to rifampicin varies during the cell cycle (between 1 and $40 \mu \mathrm{g} \mathrm{ml}^{-1}$; Whittenbury \& Dow, 1977; N. W. Scott \& C. S. Dow, unpublished data), the inhibitory effect of this antibiotic on holoenzyme was investigated in vitro. The purified enzyme was very sensitive: with T7D111 DNA and DNA extracted from $R$. vannielii, $50 \%$ inhibition was achieved with approximately $5 \mathrm{ng}$ rifampicin $\mathrm{ml}^{-1}$ (Fig. 6).

\section{Concluding remarks}

It is clear from the data presented here that the major form of RNA polymerase in $R$. vannielii is similar in many respects to the enzymes of other Gram-negative bacteria. The $M_{\mathrm{r}}$ values of the subunits were similar to those of $E$. coli except for the sigma factor, $M_{\mathrm{r}} 98000$, which was significantly larger. This preliminary investigation, however, leaves many unanswered questions. For instance, why do sigma and alpha subunits appear to be doublets? Are any of the subunits phosphorylated, as is the case in E. coli (Enami \& Ishihama, 1984)? What is the function of the $M_{\mathrm{r}} 78000$ protein ? Why is $R$. vannielii DNA such a poor template for the enzyme as compared with T7 DNA?

We do not yet know whether enzymes isolated from different cell types have different transcription properties; if they do, this could be due either to changes in the core-associated proteins or to subunit modification. There is some evidence for changes in subunit composition of the RNA polymerase, but it is not known how these would affect protein synthesis (Dow et al., 1985).

This work was supported by a grant from the Science and Engineering Research Council.

\section{REFERENCES}

ALberTs, B. M. \& HerRICK, G. (1971). DNA-cellulose chromatography. Methods in Enzymology 21, 198217.

AmemiYa, K., Wu, C. W. \& ShapiRo, L. (1977). Caulobacter crescentus RNA polymerase purification and characterization of holoenzyme and core polymerase. Journal of Biological Chemistry 252, 41574165.

BuRgess, R. R. (1969). A new method for the large scale purification of Escherichia coli deoxyribonucleic acid-dependent ribonucleic acid polymerase. Journal of Biological Chemistry 244, 6160-6167.

Burgess, R. R. (1976). Purification and physical properties of $E$. coli RNA polymerase. In $R N A$ Polymerase, pp. 69-100. Edited by R. Losick \& M. Chamberlin. Cold Spring Harbor, NY: Cold Spring Harbor Laboratory.

BURGESS, R. R. \& JENDRISAK, J. J. (1975). A procedure for the rapid, large-scale purification of Escherichia coli DNA-dependent RNA polymerase involving polymin $\mathrm{P}$ precipitation and DNA-cellulose chromatography. Biochemistry 14, 4634-4638.

DoI, R. H. (1982). RNA polymerase of Bacillus subtilis. In The Molecular Biology of the Bacilli, vol. 1, Bacillus subtilis, pp. 72-106. Edited by D. D. Dubnau. New York: Academic Press. 
Dow, C. S., Whittenbury, R. \& CARr, N. G. (1983). The 'shut-down' or 'growth precursor' cell - an adaptation for survival in a potentially hostile environment. Symposia of the Society for General Microbiology 34, 187-247.

Dow, C. S., Kelly, D. J., OAKley, C. J., Porter, D., SCOTt, N. W., SWoboda, U. \& WhitTEnbURY, R. (1985). Differentiation events in Rhodomicrobium vannielii. Annales de l'Institute Pasteur/Microbiologie 136A, 19-28.

Enami, M. \& Ishihama, A. (1984). Protein phosphorylation in Escherichia coli and purification of a protein kinase. Journal of Biological Chemistry 259, 526-533.

Friesen, J. D., Parker, J., Watson, R. J., Bendiak, D., Reeh, S. U., Pedersen, S. \& Fill, N. P. (1976). A transducing bacteriophage carrying the structural gene for elongation factor Ts. Molecular and General Genetics 148, 93-98.

Fukuda, R., Ishihama, A., Saitoh, T. \& Taketo, M. (1977). Comparative studies of RNA polymerase subunits from various bacteria. Molecular and General Genetics 154, 135-144.

Gonzalez, N., Wiggs, J. \& Chamberlin, M. J. (1977). A single procedure for resolution of Escherichia coli RNA polymerase holoenzyme from core polymerase. Archives of Biochemistry and Biophysics 182, 404-408.

Gross, C., Engbaek, F., Flammang, T. \& Burgess, R. (1976). Rapid micro-method for the purification of Escherichia coli ribonucleic acid polymerase and the preparation of bacterial extracts active in ribonucleic acid synthesis. Journal of Bacteriology 128, 382-389.

HAYWARD, R. S. \& FYFE, S. (1978). Over-synthesis and instability of sigma proteins in a merodiploid strain of Escherichia coli. Molecular and General Genetics 159, 89-99.

HiNkLE, D. C. \& Chamberlin, M. J. (1972). Studies of the binding of Escherichia coli RNA polymerase to DNA. (1) The role of sigma subunit in site selection. Journal of Molecular Biology 70, 157-185.

Jaehning, J. A., Wiggs, J. L. \& Chamberlin, M. J. (1979). Altered promoter selection by a novel form of Bacillus subtilis RNA polymerase. Proceedings of the National Academy of Sciences of the United States of America 76, 5470-5474.

KUDO, T. \& DoI, R. H. (1981). Free factor of Escherichia coli RNA polymerase can bind to DNA. Journal of Biological Chemistry 256, 9778-9781.

K UDO, T., JAFFE, D. \& DoI, R. H. (1981). Free sigma subunit of Bacillus subtilis RNA polymerase binds to DNA. Molecular and General Genetics 181, 63-68.

LAEMMLI, U. K. (1970). Cleavage of structural proteins during the assembly of the head of bacteriophage T4. Nature, London 227, 680-685.

Losick, R. \& Pero, J. (1981). Cascades of sigma factors. Cell 25, 582-584.

Lotz, W., Fees, H., WOHLLEBen, W. \& BURKaRdT, H. J. (1981). Isolation and characterization of the DNA-dependent RNA polymerase of Rhizobium leguminosarum 300. Journal of General Microbiology 125, 301-309.

McDonell, M. W., Simon, M. N. \& Studier, F. W. (1977). Analysis of restriction fragments of T7 DNA and determination of molecular weights by electrophoresis and alkaline gels. Journal of Molecular Biology 110, 119-146.

MARMUR, J. (1961). A procedure for the isolation of deoxyribonucleic acid from microorganisms. Journal of Molecular Biology 3, 208-218.

O'Farrell, P. H. (1975). High resolution two-dimensional electrophoresis of proteins. Journal of Biological Chemistry 250, 4007-4021.

OUCHTERLONY, O. (1958). Diffusion-in-gel methods for immunological analysis. In Progress in Allergy, vol. 5, pp. 1-78. Edited by P. Kallos. Basel \& New York: S. Karger.

OvchinNIKov, Y. A., LIPKIN, V. M., Modyanov, N. N., Chertov, O. Y. \& Smirnov, Y. V. (1977). Primary structure of the $\alpha$-subunit of DNA-dependent RNA polymerase from $E$. coli. FEBS Letters 76, 108-111.

Ovchinnikov, Y. A., Monasturskaya, G. S., Gubanov, V. V., Guryev, S. O., Chertov, O. Y., Modyanov, N. N., Grinkevich, V. A., Makarova, I. A., Marchenko, T. V., Polovnikova, I. N., Lipkin, V. M. \& Sverdlov, E. D. (1981). The primary structure of $E$. coli RNA polymerase. Nucleotide sequence of the rpo $B$ gene and amino acid sequence of the $\beta$-subunit. European Journal of Biochemistry 116, 621-629.

PotTs, L. E. \& Dow, C. S. (1979). Nucleic acid synthesis during the developmental cycle of the Rhodomicrobium vannielii swarm cell. FEMS Microbiology Letters 6, 393-395.

REgensBuRger, B. \& HENNECKE, H. (1983). RNA polymerase from Rhizobium japonicum. Archives of Microbiology 135, 103-109.

Sternbach, H., ENgelhardt, R. \& Lezius, A. G. (1975). Rapid isolation of highly active RNA polymerase from Escherichia coli and its subunits by matrix-bound Heparin. European Journal of Biochemistry 60, 51-55.

TAYLOR, S. C. \& Dow, C. S. (1980). Ribulose-1,5bisphosphate carboxylase from Rhodomicrobium vannielii. Journal of General Microbiology 116, 81-87.

WeHRli, W. \& Staehelin, M. (1971). Actions of the rifamycins. Bacteriological Reviews 35, 290-309.

WhITTENBURY, R. \& Dow, C. S. (1977). Morphogenesis and differentiation in Rhodomicrobium vannielii and other budding and prosthecate bacteria. Bacteriological Reviews 41, 754-808.

Wiggs, J. L., Bush, J. W. \& Chamberlin, M. J. (1979). Utilization of promoter and terminator sites on bacteriophage T7 DNA by RNA polymerases from a variety of bacterial orders. Cell 16, 97-109.

Wray, W., Boulikas, T., Wray, V. P. \& HaNCOCK, R. (1981). Silver staining of proteins in polyacrylamide gels. Analytical Biochemistry 118, 197-203. 